\title{
Thermal Comfort of Two-Layer Knitted Fabrics for Compression Garment
}

\author{
Pimpawan Kumphai, Central Michigan University, USA \\ Su Kyoung An, Central Michigan University, USA \\ Natalie Zainea, Central Michigan University, USA \\ Pawarin Tuntariyanond, Kasetsart University, Thailand
}

Keywords: thermal comfort, knit fabrics, multilayer, compression garment

Compression garments is designed to provide pressure to the body for health purposes. Some people wear the compression garments to support the blood circulation in some parts of their bodies. Some people wear it for recovering purpose after medical surgery (Wang, Felder, \& Cai, 2011). For example, in medical therapy, bandages are wrapped several layers to provide desire compression; compression stockings are developed to help with blood circulations (Xiong \& Tao, 2018); and dynamic compression garment with additional layers of fabrics is used to help enhancing postural control in children with cerebral palsy (MacKenzie \& McIlwain, 2015). Particularly, dynamic compression garment for children with cerebral palsy was designed with layering of strong elastic and stretch knitted fabrics to provide more strength, shape, or pressure to the body for supporting the patient's postures. According to the severity of illness, the fabric selection and fabric layering combination are differently applied. However, limited research has focused on the effect of number of layers of knitted fabric for compression garment. In this study, the combinations of two-layer fabrics were tested for thermal comfort; specifically, dry thermal resistance $\left(\mathrm{R}_{\mathrm{ct}}\right)$ and air permeability values. Two hypotheses were developed.

$H_{1}$ : There are significant differences in dry thermal resistance $\left(R_{c t}\right)$ among the two-layer combinations of knitted fabrics.

$\mathrm{H}_{2}$ : There are significant differences in air permeability among the two-layer combinations of knitted fabrics.

The three knitted fabrics that are widely used to make underwear and compression garments were selected. Table 1 shows the fiber content, weight, and microscopic views of each fabric. A total of six all possible combinations of two-layer from three knitted fabrics were tested (A1B1, B1C1, A1C1, A2, B2, and C2).

The Sweating Guarded Hot-Plate (SGHP) manufactured by Measurement Technology Northwest was used to conduct the dry thermal resistance $\left(\mathrm{R}_{\mathrm{ct}}\right)$ test following ASTM F 1868-09 standard. The specimens were prepared and conditioned for a minimum 12 hours at $35 \pm 0.5^{\circ} \mathrm{C}$ temperature and $65 \pm 4 \mathrm{RH} \%$ humidity of environmental chamber before tests. The TEXTEST Air Permeability Tester (model: FX 3300 LabAir IV) was utilized to measure air permeability value of fabric combination according to ASTM D 737-04 standard.

Page 1 of 3

(c) 2020 The author(s). Published under a Creative Commons Attribution License (https://creativecommons.org/licenses/by/4.0/), which permits unrestricted use, distribution, and reproduction in any medium, provided the original work is properly cited.

ITAA Proceedings, \#77 - https://itaaonline.org 
Table 1. Fabric Properties

\begin{tabular}{|c|c|c|c|c|}
\hline & & Fabric A & Fabric B & Fabric C \\
\hline \multirow[b]{2}{*}{ Fiber Content } & & 57\% Nylon & $82 \%$ Nylon & 91\% Polyurethane \\
\hline & & $\begin{array}{r}25 \% \text { Spandex } 18 \% \\
\text { Cotton }\end{array}$ & $18 \%$ Lycra & $9 \%$ Polyester \\
\hline Weight & & $195 \mathrm{~g} / \mathrm{sqm}$ & $205 \mathrm{~g} / \mathrm{sqm}$ & $324 \mathrm{~g} / \mathrm{sqm}$ \\
\hline \multirow{3}{*}{$\begin{array}{l}\text { Microscopic } \\
\text { Picture }\end{array}$} & $\begin{array}{l}\text { Front } \\
\text { View }\end{array}$ & & & \\
\hline & Back & & & \\
\hline & View & & & \\
\hline
\end{tabular}

A One-Way ANOVA was used to evaluate whether there is a difference in mean $R_{c t}$ values between the two-layer fabric combinations. Table 2 shows significant differences in $\mathrm{R}_{\mathrm{ct}}$ among six 2-layer fabric combinations $\left(\mathrm{R}_{\mathrm{ct}}: \mathrm{F}_{(5,12)}=3382.439, \mathrm{p}<.05\right)$. A Tukey Multiple Comparison procedure determines which combinations are statistically the same, and which are statistically different (Table 3). Fabric combinations that share the same letter indicate statistical similarities. It appears that the combination of two Fabric C's (C2) is distinct from the rest with the largest mean $\mathrm{R}_{\mathrm{ct}}$ of $0.25203(\mathrm{SD}=.005)$. Thus, $\mathrm{H}_{1}$ was supported.

Table 2. ANOVA Table for Dry Thermal Resistance $\left(R_{c t}\right)$ of Six 2-layered Fabric Combinations

\begin{tabular}{rrrrrrr}
\hline & Source & Sum of Squares & df & Mean Square & F & Sig. \\
\hline \multirow{3}{*}{$\mathrm{R}_{\mathrm{ct}}$} & Between Groups & .135 & 5 & .027 & 3382.439 & .000 \\
& Within Groups & .000 & 12 & .000 & & \\
Total & .135 & 17 & & & \\
\hline
\end{tabular}

Table 3. Tukey Multiple Comparison of the Average $\mathrm{R}_{\mathrm{ct}}$ Value of All Two-layer Tests

\begin{tabular}{llllll}
\hline Test & N & Mean & \multicolumn{3}{c}{ Grouping } \\
\hline C2 & 3 & 0.2520 & A & & \\
A1C1 & 3 & 0.1391 & B & \\
B1C1 & 3 & 0.1318 & B & C & \\
A2 & 3 & 0.0269 & & C & D \\
A1B1 & 3 & 0.0200 & & & D \\
B2 & 3 & 0.0125 & & & \\
\hline
\end{tabular}

Page 2 of 3

(c) 2020 The author(s). Published under a Creative Commons Attribution License (https://creativecommons.org/licenses/by/4.0/), which permits unrestricted use, distribution, and reproduction in any medium, provided the original work is properly cited.

ITAA Proceedings, \#77 - https: //itaaonline.org 
Table 4 shows significant differences in air permeability among six 2-layer fabric combinations $\left(\mathrm{R}_{\mathrm{ct}}: \mathrm{F}_{(5,48)}=118.165, \mathrm{p}<.05\right)$. A post hoc LSD test indicated that there were four groups. A1B1 has the highest air permeability $(\overline{\mathrm{x}}=127.222, \mathrm{SD}=12.468)$. The second highest group is $\mathrm{B} 2(\overline{\mathrm{x}}=117.778, \mathrm{SD}=5.495)$ and $\mathrm{B} 1 \mathrm{C} 1(\overline{\mathrm{x}}=117.0, \mathrm{SD}=3.873)$. The group with lowest air permeability is $\mathrm{A} 1 \mathrm{C} 1(\overline{\mathrm{x}}=73.422, \mathrm{SD}=6.622), \mathrm{C} 2(\overline{\mathrm{x}}=73.422, \mathrm{SD}=3.173)$, and $\mathrm{A} 2(\overline{\mathrm{x}}=72.600$, $\mathrm{SD}=7.808)$. Therefore, $\mathrm{H}_{2}$ was supported.

Table 4. ANOVA Table for Air Permeability of Six 2-layered Fabric Combinations

\begin{tabular}{crrrrrr}
\hline & Source & Sum of Squares & df & Mean Square & \multicolumn{1}{c}{ F } & Sig. \\
\hline \multirow{2}{*}{ Air } & Between Groups & 31070.075 & 5 & 6214.015 & 118.165 & .000 \\
Permeability & Within Groups & 2524.202 & 48 & 52.588 & & \\
& Total & 33594.277 & 53 & & & \\
\hline
\end{tabular}

The findings of $\mathrm{R}_{\mathrm{ct}}$ and air permeability suggested 2-layer fabric combinations are significantly differences. B2 fabric combination can best transfer heat from body to outside. A1B1 can transfer air the most. This may due to having more space or porous of the knitted construction (Ogulata \& Mavrus, 2010). Fabric combinations that include layer of fabric C perform the least in both heat and air transfer from body to outside environment. However, the combinations of fabrics A and B should be further investigated due to the similar values on both $\mathrm{R}_{\mathrm{ct}}$ and air permeability.

\section{References}

MacKenzie, C., \& McIlwain, S. (2015). Evidence-Based Management of Postural Control in a Child with Cerebral Palsy. Physiotherapy Canada. Physiotherapie Canada, 67(3), 245247. https://doi.org/10.3138/ptc.2014-34.

Ogulata R. T., \& Mavruz S. (2010). Investigation of Porosity and Air Permeability Values of Plain Knitted Fabrics. Fibres \& Textiles in Eastern Europe, 18(5), 71-75.

Xiong, Y., \& Tao, X. (2018). Compression Garments for Medical Therapy and Sports. Polymers, 10(6), 663. https://doi.org/10.3390/polym10060663

Wang, L.,Felder, M., \& Cai, J. Y. (2011). Study of Properties of Medical Compression Fabrics. Journal of Fiber Bioengineering \& Informatics, 4(1), 15-22. 